\title{
$\mathrm{NaCl} /$ Enzyme Card법에서 검출되지 않는 항-Kidd 항체 검출을 위한 효소처리 동정혈구 및 LISS/Coombs Card 추가 검사의 유용성
}

추대현* · 박수정* · 서숙원 · 양회주 · 정유선 · 권석운

울산대학교 의과대학 서울아산병원 진단검사의학과

\section{Usefulness of Additional LISS/Coombs Card Test with Enzyme-Treated Red Cells in Detecting Anti-Kidd Antibodies Not Detectable by $\mathrm{NaCl} /$ Enzyme Card Test Alone}

\author{
Daehyun Chu*, Soo Jung Park*, Suk Won Seo, Hoi Joo Yang, Yousun Chung, Seog Woon Kwon \\ Department of Laboratory Medicine, Asan Medical Center, University of Ulsan College of Medicine, Seoul, Korea
}

Background: Detection of anti-Kidd antibody is important because of its clinical significance. If detection is difficult due to weak serological reactivity or dosage effect, use of an enzyme method could be helpful. However, despite use of an enzyme method, we still observed weak reactivity of anti-Kidd antibody.

Methods: All identified anti-Kidd antibody cases from Jan 2012 to Aug 2015 in Asan Medical Center were reviewed. Antibody identification test was performed using the column agglutination technique using Bio-Rad ID-DiaPanel with LISS/Coombs card, Bio-Rad ID-DiaPanel-P with NaCl/Enzyme card, and ID-DiaPanel-P with LISS/Coombs card. The test results were compared.

Results: Sixty cases of anti-JK ${ }^{\mathrm{a}}$ or anti-JK ${ }^{\mathrm{b}}$ were detected and tested by enzyme method. Among them, 34 (56.6\%) cases showed strengthened reactivity using the ID-DiaPanel-P with NaCl/Enzyme card method. However, 26 $(43.4 \%)$ cases showed weakened reactivity. Of these, 13 cases that could be tested by an additional method using ID-DiaPanel-P with LISS/Coombs card containing anti-IgG and anti-C3d showed successfully strengthened reactivity.

Conclusion: The reactivity of anti-Kidd antibodies that was not strengthened using ID-DiaPanel-P with $\mathrm{NaCl} /$ Enzyme card method could be successfully strengthened by use of the ID-DiaPanel-P with LISS/Coombs card. (Korean J Blood Transfus 2016;27:31-37)

Key words: Enzyme-treated red cell, Unexpected antibody, Anti-Kidd antibody, Anti-C3d antibody, LISS/Coombs card

Received on February 22, 2016. Revised on April 15, 2016. Accepted on April 15, 2016

Correspondence to: Seog Woon Kwon

Department of Laboratory Medicine, Asan Medical Center, University of Ulsan College of Medicine, 88 Olympic-ro 43-gil, Songpa-gu, Seoul 05505, Korea

Tel: 82-2-3010-4504, Fax: 82-2-478-0884,E-mail: swkwon@amc.seoul.kr

${ }^{*}$ Chu D and Park SJ contributed equally as co-first authors.

@) This is an Open Access article distributed under the terms of the Creative Commons Attribution Non-Commercial License (http://creativecommons.org/licenses/by-nc/4.0) which permits unrestricted non-commercial use, distribution, and reproduction in any medium, provided the original work is properly cited.

Copyright (C) 2016 The Korean Society of Blood Transfusion 


\section{서 론}

항-Kidd 항체는 1950년대 태아신생아용혈성질 환이 발생한 사례의 산모와 용혈성수혈반응을 보 인 환자의 혈청에서 발견된 이래, 급성 및 지연성 용혈성수혈반응과 신생아 용혈성질환을 일으키 는 원인으로 밝혀져 있다. ${ }^{1,2)}$ 그러나 항-Kidd 항체 는 혈청학적으로 매우 다양한 반응성을 나타내고 용량효과(dosage effect)를 보이기 때문에 검출하 기 어려우며, 종종 다른 항체와 복합적으로 나타 나기도 한다. ${ }^{3)}$ 일반적으로 항-Kidd 항체는 항글 로불린법으로 검출하며 효소처리된 적혈구의 사 용으로 반응이 증강되기 때문에, ${ }^{2)}$ 보다 정확한 항체 동정을 위해서 효소법을 병행한다. 그러나 효소법에서 오히려 반응이 약해지거나 반응하지 않는 경우를 경험하여 정확한 항체를 동정하는데 어려움을 종종 경험하였다. 저자들은 그 빈도와 원인을 분석하고 이에 대한 문헌고찰을 통하여 해결방법을 강구하여 효소법에서 미검출된 항-Kidd 항체를 검출하는데 도움이 될 수 있는 방법을 제 시하고자 한다.

\section{대상 및 방법}

서울아산병원에서 2012년 1월부터 2015년 8월 까지 3년 8개월 동안 시행한 항체동정검사에서 확인된 항- $\mathrm{Jk}^{\mathrm{a}}$ 와 항-Jk 65 건 중 효소법을 추가 시 행한 60건을 대상으로 하였다. 연구대상에는 항-Kidd 항체가 다른 종류의 동종항체 및 자가항체와 함 께 동정된 경우도 포함하였다.

항체선별검사는 LISS/Coombs card (Bio-Rad, Cressier, Switzerland)를 이용한 원주응집법(column agglutination technique)으로 시행하였다. 항체선 별검사 선별혈구는 ID-DiaCell I\&II (Bio-Rad, Cressier, Switzerland)를 사용하였으며 동정혈구 $50 \mu \mathrm{L}$
에 환자 혈청 $25 \mu \mathrm{L}$ 를 첨가하고 $37^{\circ} \mathrm{C}$ 에서 15 분간 항온 후 $1030 \mathrm{rpm}$ 에서 10 분간 원심분리하여 응집 을 확인하였다. 응집이 발생하지 않은 음성부터 반응강도에 따라 \pm 부터 $4+$ 까지 판독하였다. 판 독 결과 항체선별검사에서 양성이 나온 경우, 그 원인 항체를 규명하기 위하여 항체동정검사를 시 행하였다.

항체동정검사 중 항글로불린법은 ID-DiaPanel (Bio-Rad, Cressier, Switzerland)의 동정혈구와 LISS/ Coombs card를 이용한 원주응집법으로 시행하였 다. ID-DiaPanel 1번부터 11번 동정혈구를 $50 \mu \mathrm{L}$ 씩 취하여 각각의 적혈구에 환자 혈청 $25 \mu \mathrm{L}$ 를 첨가한 후 항체선별검사와 동일하게 $37^{\circ} \mathrm{C}$ 에서 15 분간 항온하고, $1030 \mathrm{rpm}$ 에서 10 분간 원심분리하 여 응집 여부를 확인하고 이를 시약 제조사에서 제시한 동정 시트와 비교하여 판독하였다. 항체 동정결과 항- $\mathrm{Jk}^{\mathrm{a}}$ 와 항- $\mathrm{Jk}^{\mathrm{b}}$ 가 의심되었던 60 건에 대해 효소처리된 ID-DiaPanel-P (Bio-Rad, Cressier, Switzerland)의 동정혈구와 $\mathrm{NaCl} / \mathrm{Enzyme}$ card (Bio$\operatorname{Rad} \mathrm{AG}$, Cressier, Switzerland)를 이용하여 상기 방법과 동일하게 시행하여 판독하였다.

2014년 6월부터는 항체동정검사 시 항- $\mathrm{Jk}^{\mathrm{a}}$ 혹 은 항-Jk $\mathrm{Jk}^{\mathrm{b}}$ 가 의심되어 추가로 시행한 효소법에서 오히려 약화된 반응이 나타나거나 미검출된 13 개 검체에 대해 효소처리된 ID-DiaPanel-P의 적혈구 와 다특이성항글로불린이 포함된 LISS/Coombs card를 이용하여 항체동정검사를 추가 시행하고 이를 기존의 효소법 검사 결과와 비교하였다.

\section{결 과}

연구 기간 동안 항체동정검사에서 동정된 항-- $\mathrm{Jk}^{\mathrm{a}}$ 와 항-Jk는 총 65 건이었으며, 다른 동종항체 및 자가항체가 복합으로 동정된 경우를 포함하였다. 전체 65 건 중 항-Jk ${ }^{\mathrm{a}}$ 는 53 건(81.5\%), 항-Jk는 12 건 
(18.5\%)으로 나타났다(Table 1). 좀 더 세부적으로 살펴보면, 항-Jk 만 단독으로 동정된 경우는 22건, 항-Jk ${ }^{\mathrm{b}}$ 만 단독으로 동정된 경우는 6 건으로 항-Jk ${ }^{\mathrm{a}}$ 혹 은 항-Jk 가 단독으로 동정된 경우는 모두 28 건이 었다.

항-Kidd 항체가 다른 동종항체와 같이 동정된 경우는 18 건이었고, 이 중 가장 높은 빈도를 보인 것은 항-E 항체와 항-c 항체가 함께 동정된 경우 로 10 건이었다. 항-Jk ${ }^{\mathrm{a}}$ 가 다른 동종항체 및 자가 항체와 함께 동정된 경우가 6건이었으며, 항- $\mathrm{Jk}^{\mathrm{a}}$ 와 자가항체 두 가지만 존재한 경우는 13 건이었 으나, 항- $\mathrm{Jk}^{\mathrm{b}}$ 가 자가항체와 함께 동정된 경우는 없었다(Table 1).

항글로불린법만 시행한 5 건을 제외하고 나머 지 60건에 대해 항글로불린법에서 항-Kidd 항체

Table 1. Distribution of anti- $\mathrm{Jk}^{\mathrm{a}}$ and anti-Jk $\mathrm{Jk}^{\mathrm{b}}$ detected along with other antibodies

\begin{tabular}{|c|c|}
\hline & N (\%) \\
\hline Anti-Jk ${ }^{\mathrm{a}}$ & $53(81.5)$ \\
\hline Anti-Jk ${ }^{\mathrm{a}}$ alone & $22(41.5)$ \\
\hline Anti-Jk ${ }^{\mathrm{a}}+$ autoAb & $13(24.5)$ \\
\hline Anti-Jk $\mathrm{k}^{\mathrm{a}}+$ alloantibody & $12(22.6)$ \\
\hline Anti-E\&c & 7 \\
\hline Anti-C\&e & 2 \\
\hline Anti-E & 1 \\
\hline Anti-Le ${ }^{b}$ & 1 \\
\hline Anti-M & 1 \\
\hline Anti-Jk ${ }^{\mathrm{a}}+$ alloAb + autoAb & $6(11.3)$ \\
\hline Anti-E\&c & 4 \\
\hline Anti-E & 2 \\
\hline Anti-Jk ${ }^{\mathrm{b}}$ & $12(18.5)$ \\
\hline Anti-Jk $\mathrm{k}^{\mathrm{b}}$ alone & $6(50.0)$ \\
\hline Anti-Jk ${ }^{\mathrm{b}}+$ alloantibody & $6(50.0)$ \\
\hline Anti-E\&c & 3 \\
\hline Anti-E & 2 \\
\hline Anti-C & 1 \\
\hline Total & $65(100)$ \\
\hline
\end{tabular}

가 의심되어 추가로 효소법을 시행한 결과를 분 석하였다. 항글로불린법보다 효소법에서 응집반 응이 강화된 경우는 23 건(38.3\%)이었으며 항- $\mathrm{Jk}^{\mathrm{a}}$ 19 건, 항-Jk ${ }^{\mathrm{b}} 4$ 건이 이에 해당하였다(Table 2). 두 검사법의 반응 강도에 차이가 없는 경우는 11 건 (18.3\%)이 확인되었고 이 중 항-Jk $\mathrm{Jk}^{\mathrm{a}}$ 7건, 항-Jk ${ }^{\mathrm{b}} 4$ 건 관찰되었다. 항글로불린법에서는 상대적으로 강 한 반응을 보이면서 효소법에서 오히려 반응이 약화되었으나 음성은 아닌 경우는 10건(16.7\%)이 관찰되었으며 항-Jk ${ }^{\mathrm{a}}$ 9건, 항-Jk ${ }^{\mathrm{b}} 1$ 건이었다. 마지 막으로 효소법에서 음성으로 미검출된 경우는 16건 (26.7\%)이었으며 16건 모두 항-Jk 였다.

항글로불린법에 의해 환자 혈청 내에 항-Kidd 항체가 있을 것으로 의심되지만 효소법에서 오히 려 반응이 약해지거나 소실된 경우 정확한 항체 검출을 위해 2014년 6월부터 효소처리된 적혈구 와 anti-IgG 및 anti-C3d를 포함하는 LISS/Coombs card를 이용해 추가 검사를 시행하였다. 효소법에 서 반응이 소실되어 음성으로 나타난 항-Jk $\mathrm{Jk}^{\mathrm{a}}$ 건,

Table 2. Reactivity of anti-Kidd antibodies tested using ID-DiaPanel-P with NaCl/Enzyme card compared to ID-DiaPanel with LISS/Coombs card

\begin{tabular}{lc}
\hline Reactivity & N (\%) \\
\hline Strengthened & $23(38.3)$ \\
Anti-Jk $^{\mathrm{a}}$ & 19 \\
Anti-Jk $^{\mathrm{b}}$ & 4 \\
No change & $11(18.3)$ \\
Anti-Jk & 7 \\
Anti-Jk $^{\mathrm{b}}$ & 4 \\
Weakened $^{\mathrm{a}}$ & $10(16.7)$ \\
Anti-Jk & 9 \\
Anti-Jk & 1 \\
Disappeared & $16(26.7)$ \\
Anti-Jk & 16 \\
Anti-Jk & 0 \\
Total & $60(100)$ \\
\hline
\end{tabular}


효소법에서 반응이 약화된 항-Jk $\mathrm{k}^{\mathrm{a}}$ 6건, 항-Jk $\mathrm{b}^{\mathrm{b}} 1$ 건 등 총 13 개의 검체에 대해 추가 검사가 진행되었 고, 그 결과 13건 모두에서 $\mathrm{NaCl} /$ Enzyme card를 사용하는 효소법보다 응집반응이 더 강하게 나타 나는 현상을 관찰할 수 있었다(Table 3).

\section{고 찰}

항-Kidd 항체는 $\operatorname{IgG}$ 와 $\mathrm{IgM}$ 항체로 구성되며, 이 중 일부가 보체와 결합하여 적혈구의 용혈을 일으킬 수 있다고 알려져 있다. ${ }^{4)} \mathrm{Kidd}$ 항원에 대 한 동종면역은 임신이나 수혈에 의한 항원노출에 기인한다. 이러한 항원자극요인이 사라지면 항체 농도는 급감하여 2,5$)$ 수혈 전 검출이 어렵기 때문 에 용혈성수혈반응, 특히 지연성 용혈성수혈반응 의 $1 / 3$ 을 차지하는 흔한 원인이 되며, 항-Kidd 항 체에 의한 용혈성수혈반응은 다수 보고되고 있 다.,3-8) 따라서 수혈 전 항-Kidd 항체의 정확한 동 정이 수혈부작용의 예방을 위해서 중요한데, 이 러한 항-Kidd 항체는 혈청학적 특징의 다양성, 혈
청 내 낮은 항체 역가 등으로 인하여 검출하기가 어려워 일반적으로 다특이성항글로불린(polyspecific anti-human globulin)으로 검출하며 ${ }^{8)}$ 효소처리된 적혈구의 사용으로 검출률을 높일 수 있다. 그러 나 항-Jk의 경우, 반응을 증강시키기 위해 시행한 효소법에서 반응이 소실된다는 보고가 있으며,10) 이는 저자들도 종종 경험한 바 있다.

저자들이 조사한 3년 8개월간의 자료에서 항-Kidd 항체가 동정된 건 수는 총 65건이었다. 항-Kidd 항체는 종종 다른 동종항체 및 자가항체와 함께 복합적으로 나타나는 것으로 알려져 있는데, ${ }^{11)}$ 저자들의 조사 결과도 이를 반영하듯 동정된 항Kidd 항체 65 건 중 항-Jk ${ }^{\mathrm{a}}$ 혹은 항-Jk $\mathrm{Jk}^{\mathrm{b}}$ 가 단독으로 동정된 경우는 28 건(43.1\%)에 불과하였다.

항체동정검사 시 항글로불린법만 시행한 경우 는 총 65 건 중 5 건(7.7\%)이었고, 그 외의 60 건 (92.3\%)에 대해 효소법 등 추가 검사를 시행하였 다. 효소법을 시행한 60 건 중 23 건(38.3\%)은 효소 법에서 강한 응집반응을 보여 검출 가능했으며 이를 통해 기존에 알려진 바대로 효소처리된 적

Table 3. Comparison of reactivity of 13 cases tested

\begin{tabular}{lcccc} 
Case & Antibody identified & $\begin{array}{c}\text { ID-DiaPanel }+ \\
\text { LISS/Coombs card test }\end{array}$ & $\begin{array}{c}\text { ID-DiaPanel-P } \\
\text { NaCl/Enzyme card test }\end{array}$ & $\begin{array}{c}\text { ID-DiaPanel-P }+ \\
\text { LISS/Coombs card test }\end{array}$ \\
\hline 1 & Anti-Jk $^{\mathrm{a}}$ & $0 \sim \pm$ & $0 \sim \pm$ & $\pm \sim 2+$ \\
2 & Anti-Jk $^{\mathrm{a}}$ & $\pm \sim 2+$ & $0 \sim 2+$ & $1+\sim 3+$ \\
3 & Anti-Jk $^{\mathrm{a}}$ & $2+$ & \pm & $2+\sim 3+$ \\
4 & Anti-Jk $^{\mathrm{a}}$ & $\pm \sim 1+$ & $0 \sim \pm$ & $1+\sim 2+$ \\
5 & Anti-Jk $^{\mathrm{a}}$ & $1+\sim 2+$ & $0 \sim 2+$ & $2+\sim 3+$ \\
6 & Anti-Jk $^{\mathrm{a}}$ & $1+\sim 2+$ & $0 \sim 1+$ & $2+\sim 3+$ \\
7 & Anti-Jk $^{\mathrm{a}}$ & $1+$ & 0 & $2+$ \\
8 & Anti-Jk $^{\mathrm{a}}$ & $0 \sim \pm$ & 0 & $1+\sim 2+$ \\
9 & Anti-Jk $^{\mathrm{a}}$ & $1+$ & 0 & $3+$ \\
10 & Anti-Jk $^{\mathrm{a}}$ & $2+$ & 0 & $2+$ \\
11 & Anti-Jk $^{\mathrm{a}}$ & $1+\sim 2+$ & 0 & $1+\sim 3+$ \\
12 & Anti-Jk $^{\mathrm{a}}$ & $1+$ & 0 & $2+$ \\
13 & Anti-Jk $^{\mathrm{b}}$ & $1+\sim 2+$ & $1+\sim 2+$ & $2+\sim 4+$ \\
\hline
\end{tabular}


혈구가 항-Kidd 항체 검출률을 높일 수 있음을 확 인하였다.

하지만 앞에서 언급한 대로 항글로불린법과 효소법 간 반응강도에 변화가 없었던 11 건 (18.3\%)을 제외하고 효소법에서 오히려 응집반응 이 약양성이 되거나 음성으로 미검출된 경우가 26 건으로 약 $43 \%$ 를 차지했다. 이처럼 효소법에 서 반응이 약해지는 원인으로는 두 가지를 생각 해볼 수 있다.

첫째, 항-Kidd 항체의 특징 중 하나인 보체와의 결합성으로 Storry ${ }^{2}$ 는 항-Kidd 항체의 약 $50 \%$ 가 보체와 결합할 수 있다고 했으며, Villa 등)도 항 -Kidd 항체는 보체결합능이 있는 $\mathrm{IgG}$ 항체라고 했다. Lown 등 ${ }^{12,13)}$ 은 보체결합성 동종항체가 많 은 양의 보체를 효소처리된 적혈구에 결합시켜 결과적으로 적혈구의 응집반응이 약화되는 원인 이 될 수 있고, 이러한 보체활성을 억제하기 위해 ethylenediaminetetraacetic acid (EDTA)를 첨가하 여 보체를 비활성화시키면 효소법에서의 반응을 증가시킬 수 있다고 하였다. 국내에서도 EDTA의 첨가로 보체활성을 억제하여 효소법에서의 반응 이 강화되었다는 Choi 등")의 보고가 있었다. 또한 Yates 등 ${ }^{14)}$ 은 항- $-\mathrm{kk}^{\mathrm{a}} / \mathrm{Jk}^{\mathrm{b}}$ 가 들어있는 43 개의 혈청 중 일부에서 보체와의 결합이 관찰되었다고 보고 했다. Villa 등은 항-Kidd 항체는 일반적으로 $\mathrm{IgG}$ 항체 단독 혹은 $\mathrm{IgG}$ 와 $\mathrm{IgM}$ 항체가 함께 존재하고 순수한 IgM 항체는 드물지만, $\mathrm{IgM}$ 항체는 보체와 결합을 하며, 항보체성분(anti-complement component)이 있는 다특이성항글로불린을 사용하면 검 출할 수 있다고 보고했다. 위와 같은 여러 문헌고 찰을 통해 항-Kidd 항체 일부가 보체결합성을 가 지며 이는 효소법에서의 응집반응을 약화시킬 수 있는 요인이 될 수 있을 것이다.

둘째, 기존 효소법에서는 항글로불린법에 쓰이 는 LISS/Coombs card가 아닌 다특이성항글로불
린이 들어있지 않은 $\mathrm{NaCl} /$ Enzyme card를 사용한 다는 점이 원인이 될 수 있다. 동정혈구가 효소처 리되었더라도 검사의 민감도를 증가시킬 수 있는 항글로불린이 없기 때문에 $\mathrm{IgG}$ 형태의 비예기항 체는 특히 검출이 어려울 수 있다.

효소법에서 응집반응이 약하게 나타난 원인으로 위에 언급한 것처럼 보체결합성을 갖는 항-Kidd 항체가 효소처리 동정혈구에 보체를 결합시켜 결 과적으로 응집반응을 감소시키는 가능성과 기존 효소법에서는 anti-IgG 및 anti-C3d가 들어있지 않 은 $\mathrm{NaCl} / \mathrm{Enzyme}$ card를 이용한다는 점 등 크게 두 가지 원인을 생각하였고 이를 개선하기 위해 anti-IgG 및 anti-C3d ${ }^{10)}$ 가 포함된 LISS/Coombs card와 효소처리된 적혈구를 사용해 추가적으로 항체동 정검사를 시행하기로 하였다.

O’Brien 등 ${ }^{15}$ 은 DiaMed ID LISS/Coombs card (DiaMed $\mathrm{GmbH}$, Cressier, Switzerland)의 다특이성 항글로불린의 구성성분 중에 anti-C3d와 같은 항 보체성분이 포함되어 있으며 이를 통해 효소법에 서 반응이 소실된 보체결합성 항-Jk ${ }^{\mathrm{a}}$ 의 응집반응 을 증가시킬 수 있음을 보고하였는데, 국내에서 통용되고 있는 Bio-Rad사의 LISS/Coombs card (Bio-Rad, Cressier, Switzerland)에도 마찬가지로 anti-IgG와 함께 anti-C3d가 들어있음을 확인한 저 자들은 $\mathrm{NaCl} /$ Enzyme card 대신 LISS/Coombs card 사용을 통한 항-Kidd 항체의 동정을 기대하였다. 효소처리된 적혈구와 LISS/Coombs card를 이 용해 추가 검사를 시행한 결과 효소처리된 적혈 구와 $\mathrm{NaCl} / \mathrm{Enzyme}$ card를 사용하는 효소법보다 응집반응이 강화되었다. 이 결과는 위에 서술한 대로 anti-IgG의 존재로 인한 항-Kidd 항체 응집반 응 증가 가능성과 더불어 항보체성분이 함께 있 는 다특이성항글로불린의 사용 때문이라고 생각 된다.

결론적으로 anti-IgG와 anti-C3d 중 무엇이 응집 
반응 증가에 더 큰 영향을 미쳤는가에 대한 확인 은 어려웠지만 항체동정검사에서 항-Kidd 항체가 의심되어 효소법을 시행했을 때 반응이 오히려 약해지는 경우, 효소처리된 적혈구와 anti-IgG 및 anti-C3d가 있는 LISS/Coombs card를 이용해 추가 검사를 시행하면 검출률을 높일 수 있음을 확인 하였다. 또한 항체선별검사에서 양성이 나와 항 체동정검사를 시행했으나 항체 동정이 되지 않는 경우, 검출을 위한 다양한 방법의 시도가 필요하 며 향후 본 연구가 항-Kidd 항체에 대한 추가적인 연구를 위해 중요한 기초자료가 될 수 있을 것으 로 생각된다.

\section{요 약}

배경: 임상적으로 중요한 항-Kidd 항체를 정확 히 검출하는 것은 매우 중요하다. 약하게 나타나 는 혈청학적 반응과 용량효과로 인해 검출이 쉽 지 않을 경우 효소법이 도움이 되는데 효소법의 사용에도 불구하고 저자들은 항-Kidd 항체가 지 속적으로 약한 응집반응을 보이는 것을 경험하였다.

방법: 2012년 1월부터 2015년 8월까지 서울아 산병원에서 항체동정검사를 통해 확인된 모든 항-Kidd 항체를 분석하였다. 원주응집법을 이용 해 Bio-Rad ID-DiaPanel 동정혈구와 LISS/Coombs card, Bio-Rad ID-DiaPanel-P 동정혈구와 NaCl/Enzyme card를 사용하여 항체동정검사를 시행하였고, 추 가적으로 ID-DiaPanel-P 동정혈구와 LISS/Coombs card로 검사하여 이들의 검사 결과를 비교하였다.

결과: 총 60 건의 항- $\mathrm{Jk}^{\mathrm{a}}$ 와 항- $\mathrm{Jk}^{\mathrm{b}}$ 가 검출되어 효 소법을 추가 시행하였고 34 건(56.6\%)은 IDDiaPanel-P 동정혈구와 $\mathrm{NaCl} / \mathrm{Enzyme} \mathrm{card}$ 를 사용 하는 효소법에서 강한 응집반응이 확인되었으나 나머지 26건(43.4\%)은 효소법에서 반응이 약화되 었다. 이중 13건에 대해 ID-DiaPanel-P 동정혈구
와 anti-IgG 및 anti-C3d를 포함하는 LISS/Coombs card를 병용하여 추가 검사를 시행하여 응집반응 이 더 강하게 나타나는 현상을 관찰할 수 있었다.

결론: ID-DiaPanel-P 동정혈구와 $\mathrm{NaCl} / \mathrm{Enyme}$ card를 사용해 검사했을 때 강해지지 않았던 항 -Kidd 항체의 응집반응이 ID-DiaPanel-P 동정혈구 와 LISS/Coombs card를 이용한 검사에 의해 성공 적으로 강화될 수 있다.

\section{References}

1. Harvey GK, David JA. Mollison's blood transfusion in clinical medicine. 12th ed. Hoboken: Wiley-Blackwell, 2013:221, 307, 315-6

2. Storry JR. Other blood group systems and antigens. In: Fung Mk, Grossman BJ, Hillyer C, Westhoff CM. Technical manual. 18th ed. Bethesda: American Association of Blood Banks, 2014:351-2

3. Malhotra S, Kaur G, Singh L, Basu S, Lehl SS. Delayed hemolytic reaction due to anti $\mathrm{Jk}^{\mathrm{a}}$ alloimmunization. IJBTI 2011;1:16-9

4. Stowell SR, Winkler AM, Maier CL, Arthur $\mathrm{CM}$, Smith NH, Girard-Pierce KR et al. Initiation and regulation of complement during hemolytic transfusion reactions. Clin Dev Immunol 2012;2012:307093

5. Han KS, Park MH, Kim SI. Transfusion medicine. 3rd ed. Seoul: Korea Medical Book Publisher, 2006:228-9

6. Kim S, Hur M, Lee KM, Chun W. A case of delayed hemolytic transfusion reaction in a patient with anti-c, anti-E, and anti-Jk(b). Korean J Blood Transfus 2009;20:144-50

7. Son SH, Shim BY, Joo HJ, Park JH, Kim BS, Park JY, et al. Delayed hemolytic transfusion reaction caused by anti-Jk ${ }^{\mathrm{b}}$ antibody in a renal transplant recipient. Korean J Nephrol 1999;18: 
501-4

8. Villa MA, Moulds M, Coluccio EB, Pizzi MN, Paccapelo C, Revelli N, et al. An acute haemolytic transfusion reaction due to anti-Jk ${ }^{\mathrm{a}}$. Blood Transfus 2007;5:102-6

9. Choi MS, Cho YG, Lee J, Kim DS, Lee HS, Choi SI. Two cases of Anti-Jk ${ }^{\mathrm{a}}$ whose reactivity was disappeared after enzyme treatment. Korean J Blood Transfus 2012;23:173-9

10. Shin JW, Chai GR, Bang HI, Park R, Choi TY. A case of anti-Jk $k^{a}$ whose reactivity was abolished in an enzyme gel test. Korean J Blood Transfus 2009;20:134-7

11. Christopher DH, Leslie ES, Paul MN, Kenneth CA, John DR. Blood banking and transfusion medicine. 2nd ed. Philadelphia: Elsevier, 2007:91-2
12. Lown JA, Holland PA, Barr AL. A serum factor which inhibits serologic reactions with enzyme-treated red blood cells. Transfusion 1982;22:143-6

13. Lown JA, Holland PA, Barr AL. Inhibition of serological reactions with enzyme-treated red cells by complement binding alloantibodies. Vox Sang 1984;46:300-5

14. Yates J, Howell P, Overfield J, Voak D, Downie DM, Austin EB. IgG anti-Jk $/ \mathrm{Jk}^{\mathrm{b}}$ antibodies are unlikely to fix complement. Transfus Med 1998;8:133-40

15. O'Brien P, Hopkins L, McCarthy D, Murphy S. Complement-binding anti-Jk $\mathrm{k}^{\mathrm{a}}$ not detectable by DiaMed gels. Vox Sang 1998;74:53-5 